\title{
Investigation of the Electrochemical Reduction Process of the Molybdate Ions in the Tartaric Electrolytes
}

\author{
Vusala Asim Majidzade, ${ }^{1, \star}$ Akif Shikhan Aliyev, ${ }^{1}$ Dunya Mahammad Babanly, ${ }^{1,3}$ \\ Mahmoud Elrouby $^{2}$ and Dilgam Babir Tagiyev ${ }^{1}$ \\ ${ }^{1}$ Institute of Catalysis and Inorganic Chemistry named after acad.M.Nagiyev, Azerbaijan National Academy of Sciences, \\ H. Javid ave., 113, AZ 1143, Baku, Azerbaijan \\ ${ }^{2}$ Chemistry Department, Faculty of Science, Sohag University, 82524 Sohag, Egypt \\ ${ }^{3}$ Azerbaijan State Oil and Industry University (Ufaz), Baku, Azerbaijan \\ *Corresponding author: E-mail: vuska_80@mail.ru
}

Received: $12-27-2018$

\begin{abstract}
The electrochemical reduction of molybdate ions in tartaric electrolyte has been investigated in this work. Kinetics and mechanism of the electrochemical process have been studied by cyclic and linear voltammetric polarization methods. The effect of the temperature, the rate of potential-scanning and the concentration of the molybdate ions on the electrochemical process has been also studied. By estimating the effective activation energy, it was revealed that the electroreduction process is accompanied by mixing kinetics control.
\end{abstract}

Keywords: Molybdate ions; electroreduction; tartaric acid; polarization curves; chronoamperometry

\section{Introduction}

As known, semiconductors are one of the most important materials that differ from each other by their great manifold of the physical and electrical properties, also of the chemical composition. ${ }^{1-4}$ The need for the chalcogenide semiconductor films increases with the development of the application of the new generation of solar cells. ${ }^{5}$ Today, the using of ecologically waste free solar energy is very actual connecting with the decreasing of the natural resources of the energy. Thin films of chalcogenide can be used as photo-anodes for obtaining of the electrical energy in the solar cells. One of such photosensitive semiconductor materials is molybdenum chalcogenides.

The obtaining of these films can be carried out using various methods. ${ }^{1,6}$ The most suitable method of obtaining molybdenum alloys is the electrochemical method. There are a lot of works dedicated to the electrochemical deposition of thin films of these alloys. To study well the simultaneous electrodeposition process of these compounds, at first, these components should be deposited individually.

In our previous studies, we have investigated the electroreduction and co-electrodeposition of various metals together with chalcogenides. ${ }^{7-11}$ Many works were dedicated to the electrochemical reduction of molybdate ions. Some researchers ${ }^{12}$ have investigated the electrochemical reduction of the hexavalent molybdenum ions in a solution containing tartaric acid. The formed complexes of Mo-tartarate ions were examined by spectroscopic and electrochemical methods. The resulted electrochemical peak was found to be under kinetic control at relatively high $\mathrm{pH}$ values or at a relatively low concentration of the tartaric ions. But, the electrochemical reaction occurred by protonation reaction. Moreover, some researchers ${ }^{13}$ studied the reduction of molybdenum (VI) on a pre-hydrogenated platinum electrode in acidic solutions. Reduction of molybdenum (VI) in a solution of 0.8-1.6 $\mathrm{M} \mathrm{H}_{2} \mathrm{SO}_{4}$ occurs via two main steps. The first step is a relatively high cathodic wave attributes to the reduction of Mo (V) to Mo (III), which is accompanied with the decomposition of the solvent. The second step is a relatively low cathodic wave and attributes to the reduction of Mo (VI) to Mo (V), which takes place at $+0.07 \mathrm{~V}$. The second peak seems to be controlled by a diffusion and can be used for the determination of molybdenum up to $4 \times 10^{-5}$ $\mathrm{M}$ or $6 \times 10^{-5} \mathrm{M}$. An incomplete reduction of molybdate 
ions from weak acidic and alkaline solutions within the $\mathrm{pH}$ interval from 3.0 to 9.0 has been recorded. ${ }^{14} \mathrm{~A}$ film of the hydrated oxides of molybdenum in lower oxidation states forms on the cathode surface. Products of the incomplete reduction adsorbed at the cathode and blocked its working surface.

The following up of the electroreduction process of the molybdate ions in an aqueous medium under different conditions was achieved to obtain the metallic molybdenum. ${ }^{15}$ The kinetics and the mechanism of the electroreduction process were studied by the cathodic polarization. It was observed that the rate of the electrochemical process depends on the scan rate of potential, and the temperature of the electrolyte. On the other hand, it can be concluded that the electrochemical reduction occurs in two stages. It was indicated that, during the electrochemical reduction process, the electroreduction process of the molybdate ions is accompanied by releasing of hydrogen after the potential value $-0.7 \mathrm{~V}$.

The effect of hydrogen fluoride on the cathodic reduction of molybdate ions has been investigated. ${ }^{16}$ It was indicated that the mechanism of the process is controlled by its concentration. It was found that at concentration values less than $25 \mathrm{~g} / \mathrm{L}$, the products of the electroreduction process of the molybdate ions are black or colorful precipitations. These precipitates were formed on the cathode, and the average valent of molybdenum was determined to be 3.6-4.0. In the concentration, more than $50 \mathrm{~g} / \mathrm{L}$ molybdate ions are completely reduced forming on the cathode a dense light metallic coating of thickness $3-5 \mu \mathrm{m}$ with a great adhesion to the substrate. It was concluded that the addition of hydrogen fluoric acid prevents the polymerization and aggregation of the molybdate ions.

The bright, smooth metallic coating of molybdenum with $25 \mu \mathrm{m}$ thickness is successfully deposited from aqueous electrolyte consisting high concentration of acetate. ${ }^{17-19}$ The optimal conditions for the electrodeposition of metallic molybdenum have been detected to be as follow: the current density $200-450 \mathrm{~mA} / \mathrm{cm}^{2}$ and temperature $30^{\circ} \mathrm{C} \pm 2$. The obtained coatings are amorphous, but after vacuum annealing at high temperature, they converted into crystalline films. It was concluded that the current density is the major effective factor for the precipitation of a refractory metal. ${ }^{19}$ From the published results, it has been indicated that the metallic molybdenum can be deposited through two stages through electroreduction with obtaining intermediate coating from molybdenum oxide. According to the previous studies, kinetics and mechanism of the electrochemical reduction have been investigated differently. Therefore, the main aim of our work is to study of the nature, kinetics and mechanism of the electrochemical reduction process of the molybdate ions in presence of tartaric acid as a complexing agent at different conditions, to obtain the optimal condition of obtaining a considerable coating of high quality.

\section{Experimental Part}

The preparation of the electrolyte for the electrochemical reduction of molybdate ions was carried out as follows. The desired concentration $(0.1-0.5 \mathrm{M})$ of sodium molybdate $\left(\mathrm{Na}_{2} \mathrm{MoO}_{4} 2 \mathrm{H}_{2} \mathrm{O}\right)$ was dissolved in an aqueous electrolyte of $0.007 \mathrm{M}$ tartaric acid. It is observed that, the $\mathrm{pH}$ value depends on the concentration of $\mathrm{Na}_{2} \mathrm{MoO}_{4}$ $2 \mathrm{H}_{2} \mathrm{O}$. The $\mathrm{pH}$ of the electrolyte changed in the intervals of 1.69-2.1. It is found that at the selected optimal electrolyte composition, the $\mathrm{pH}$ value is 2.1 . The polarization experiments were performed by potentiostat of IVIUMSTAT Electrochemical Interface. A three-electrode electrochemical cell of $100 \mathrm{~mL}$ volume was used. Pt and $\mathrm{Ni}$ sheets with an area of $2.2 \times 10^{-3} \mathrm{dm}^{2}$ were used as working electrodes. Silver-silver chloride electrode was used as a reference electrode. Whereas, a platinum sheet with an area of $4 \mathrm{~cm}^{2}$ was used as counter electrode. The universal ultra-thermostate UTU - 4 was utilized for regulation of the temperature of the electrochemical reaction inside the cell.

The detection of the nucleation mechanism of the electrodeposited Mo was carried out by taking the chronoamperometric method (current-time), using IVIUMSTAT potentiostat.

The morphology and the chemical composition of electrodeposits were studied by using scanning electron microscope (SEM) and energy-dispersive X-ray analysis (EDAX) of mark "Carl Zeiss Sigma", respectively. SEM images of the electrodeposited films of Mo on Ni substrate was captured using a JEOL T330A SEM from Japan. The prepared sample was captured at fixed temperature of 20 ${ }^{\circ} \mathrm{C}$ at working distance of $10 \mathrm{~mm}$, at power of $20 \mathrm{KeV}$ and at magnification factor of 3000 times from the real sample.

\section{Results and Discussion}

As known, to obtain semiconductive thin films from two or more components, the first required step was to study the electrochemical reduction processes of these components individually. Hence, the electrochemical reduction behavior of molybdate ions was investigated as shown in Fig. 1.

In the presented work, full data about the electroreduction of the molybdate ions in tartaric electrolyte were given. The cyclic polarization curves were recorded by the potentiodynamic method for finding out the kinetics and the mechanism of the electroreduction process of the molybdate ions. As seen from Fig. 1, the electrochemical reduction of the molybdate ions on the cathode occurs through two stages within the potential range of $0.47-$ $(-0.25) \mathrm{V}$. It can be expected that within interval of potential values $0.47-0.27 \mathrm{~V}$ the process occurs with respect to reaction (1), whereas within $0.27-0.00 \mathrm{~V}$ with respect to reaction (2) (Fig.1). This also corresponds to the literature data. $^{20}$ 

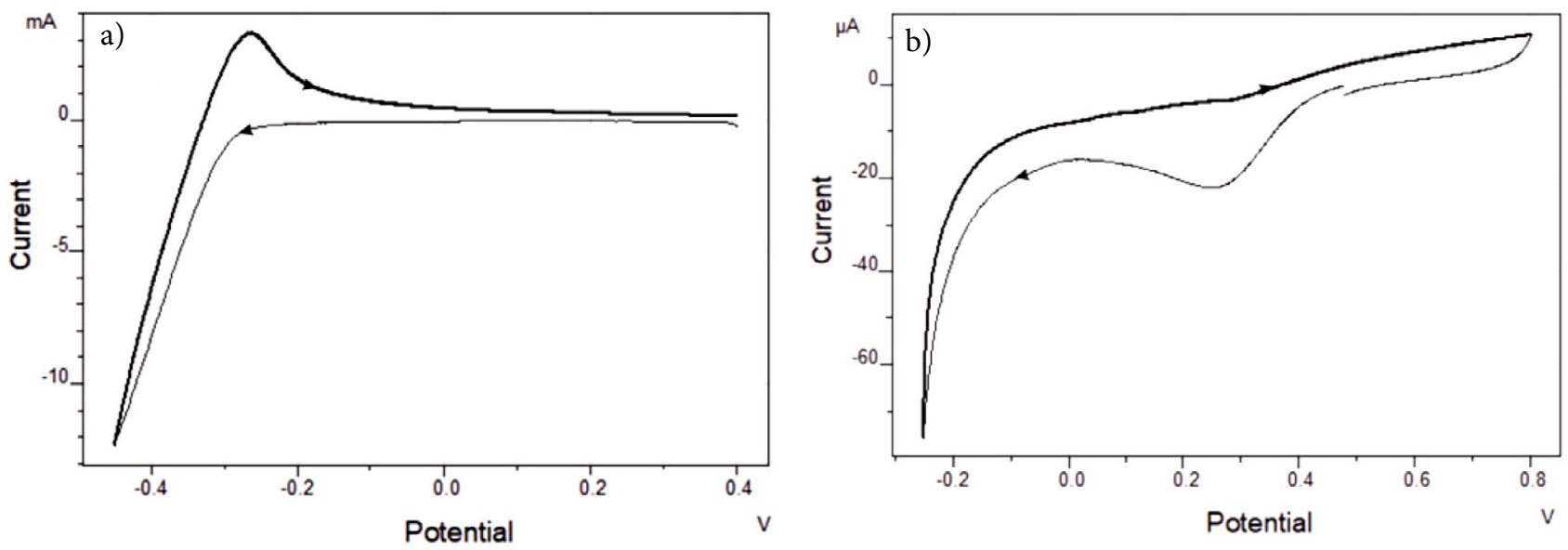

Fig. 1. Cyclic voltamperometric curves of the electroreduction process of the molybdate ions in the presence of tartaric acid on the Pt electrode. The electrolyte consists of: $0.1 \mathrm{M} \mathrm{Na}_{2} \mathrm{MoO}_{4} 2 \mathrm{H}_{2} \mathrm{O}+0.007 \mathrm{M} \mathrm{C}_{4} \mathrm{H}_{6} \mathrm{O}_{6} . \mathrm{T}=293 \mathrm{~K}, \mathrm{E}_{\mathrm{V}}=0.02 \mathrm{~V} / \mathrm{s}$. a -the general process, b- the initial stage.

$$
\begin{aligned}
& \mathrm{MoO}_{4}{ }^{2-}+4 \mathrm{H}^{+}+2 \mathrm{e}=\mathrm{MoO}_{2}+2 \mathrm{H}_{2} \mathrm{O} \\
& \mathrm{MoO}_{2}+4 \mathrm{H}^{+}+\mathrm{e}=\mathrm{Mo}^{3+}+2 \mathrm{H}_{2} \mathrm{O}
\end{aligned}
$$

After that, starting from $0.0 \mathrm{~V}$ potential value the reduction process of $\mathrm{Mo}^{3+}$ ions to metallic Mo as (3) reaction occurred:

$$
\mathrm{Mo}^{3+}+3 \mathrm{e}=\mathrm{Mo}
$$

Then, starting from the potential value of $-0.45 \mathrm{~V}$ along with electroreduction of the molybdate ions the releasing of hydrogen also occurs. Consequently, the electroreduction process was carried out up to this potential (as shown in Fig. 1 a).

The linear polarization experiments were performed as a function of temperature for determination of the kinetics of the process. The effect of temperature was investigated within a temperature range of $293-353^{\circ} \mathrm{C}$. As ob-

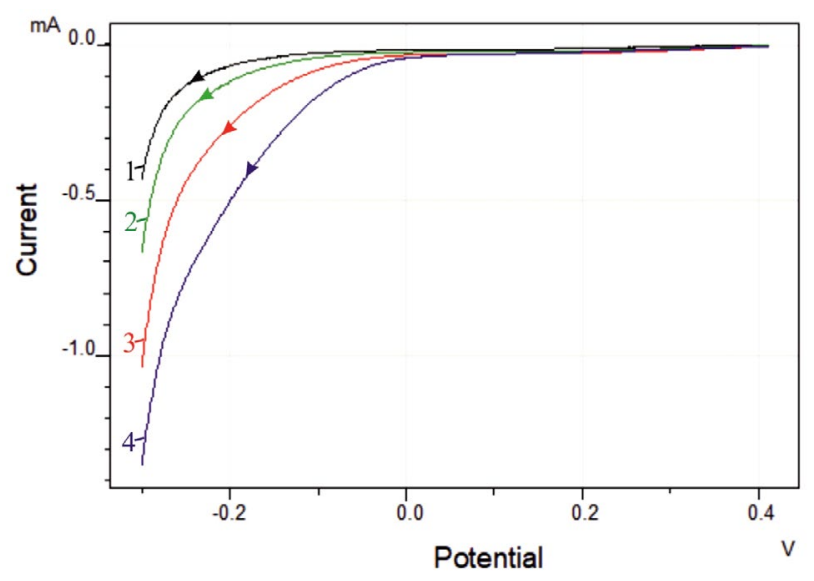

Fig. 2. The effect of temperature on the electroreduction process of the molybdate ions on the Pt electrode. Electrolyte composition in (M): $0.1 \mathrm{Na}_{2} \mathrm{MoO}_{4} 2 \mathrm{H}_{2} \mathrm{O}+0.007 \mathrm{C}_{4} \mathrm{H}_{6} \mathrm{O}_{6}$. T (K): 1- 293; 2- 313; 3 $333 ; 4-353$. At a scan rate of $\mathrm{E}_{\mathrm{V}}=0.02 \mathrm{~V} / \mathrm{s}$ served from Fig. 2, with increasing of temperature, the current increases due to the acceleration of the process (the peak on the polarization curve obtained near $\mathrm{E}=0.3$ $\mathrm{V}$, which is shown in Fig. 1b, due to an increase in the scale of the current becomes imperceptible in both Fig. 1a and Fig. 2).
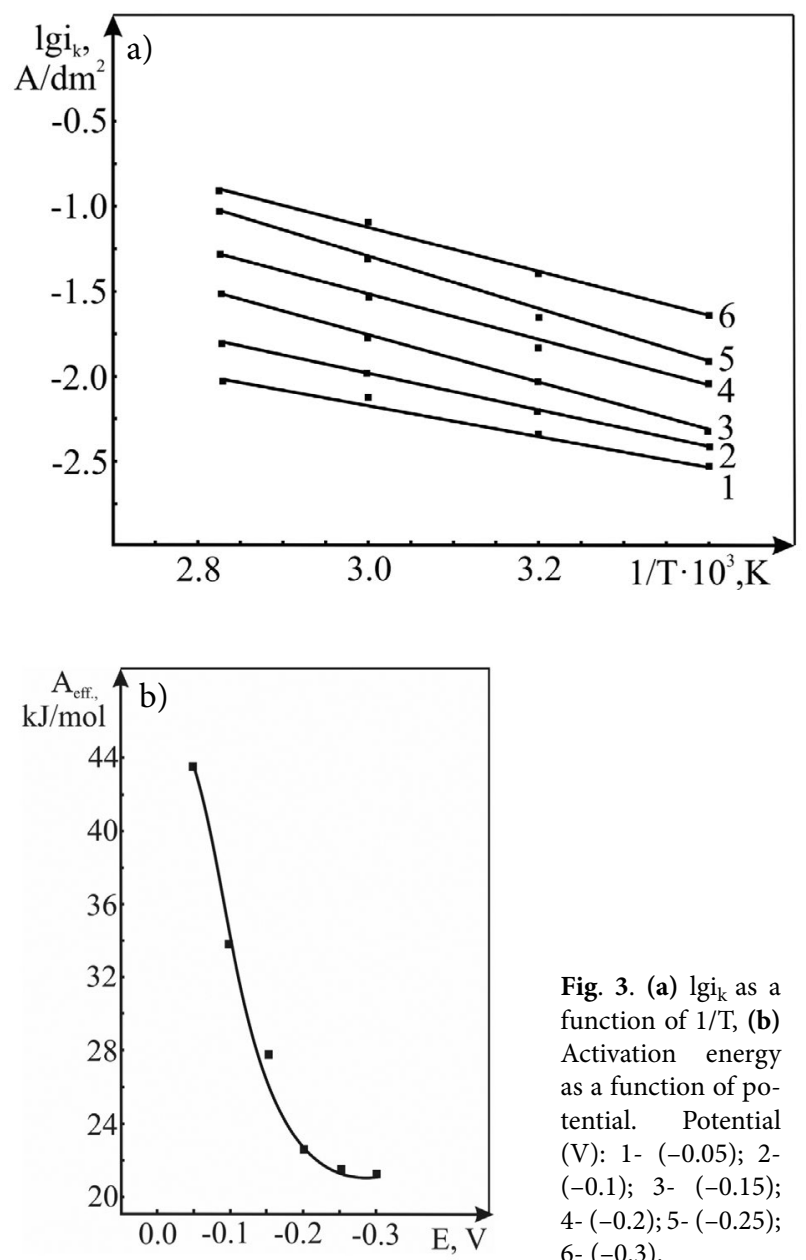

Fig. 3. (a) $\lg i_{k}$ as a function of $1 / \mathrm{T},(\mathbf{b})$ Activation energy as a function of potential. Potential (V): 1- $(-0.05) ; 2-$ $(-0.1) ; 3-\quad(-0.15)$; $4-(-0.2) ; 5-(-0.25)$; 6- $(-0.3)$. 
At a temperature of $293 \mathrm{~K}$ the reduction occurs at $-0.094 \mathrm{~V}$, but at $353 \mathrm{~K}$ it occurs at a potential of $0.0 \mathrm{~V}$. The $\lg i_{c}-1 /$ T relation was plotted within $0.0-(-0.3) \mathrm{V}$ potential range taken from the polarization curves of Fig. 2, shown in Fig. 3 (a). The value of effective activation energy obtained by the aid of equation $\mathrm{A}_{э \phi .}=-2.3$ Rtga, which indicates that the electrochemical reduction of the molybdate ions in tartaric electrolytes is accompanied by mixed kinetics mechanism. In other words, as shown in Fig. 3, at the potential values are $-0.05-(-0.2) \mathrm{B}$, the kinetics of the electroreduction process is accompanied the electrochemical, and at $-0.2-(0.3) \mathrm{B}$ the concentration polarization (Fig.3 (b)).

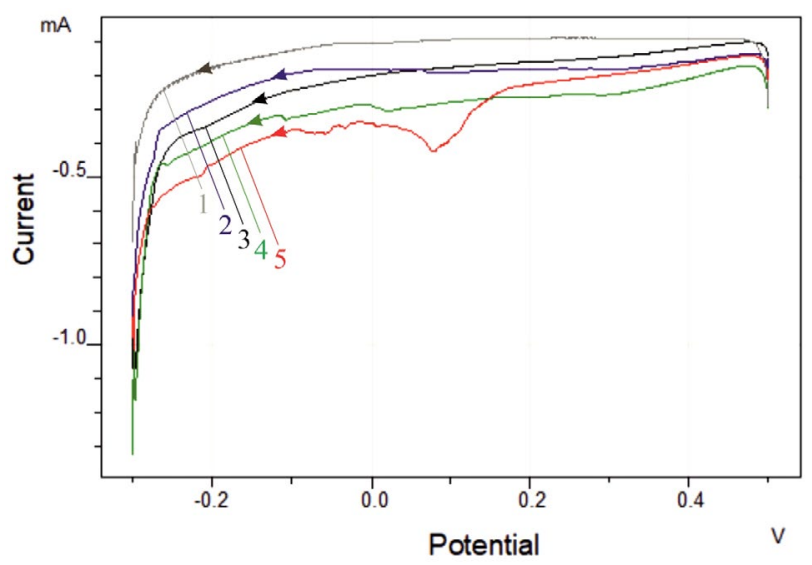

Fig. 4. The effect of concentaration of the molybdate ions to electroreduction process on the Pt electrode. The electrolyte consists of $0.007 \mathrm{C}_{4} \mathrm{H}_{6} \mathrm{O}_{6}+(\mathrm{M}) \mathrm{Na}_{2} \mathrm{MoO}_{4} 2 \mathrm{H}_{2} \mathrm{O} . \mathrm{M}=1-0.1 ; 2-0.2 ; 3-0.3 ; 4-$ $0.4 ; 5-0.5$, at $\mathrm{T}=293 \mathrm{~K}$, and $\mathrm{E}_{\mathrm{V}}=0.02 \mathrm{~V} / \mathrm{s}$.

The effect of concentration of the molybdate ions on the electroreduction process has been studied within the 0.1-0.5 mol/L interval (Fig. 4). At concentrations range of

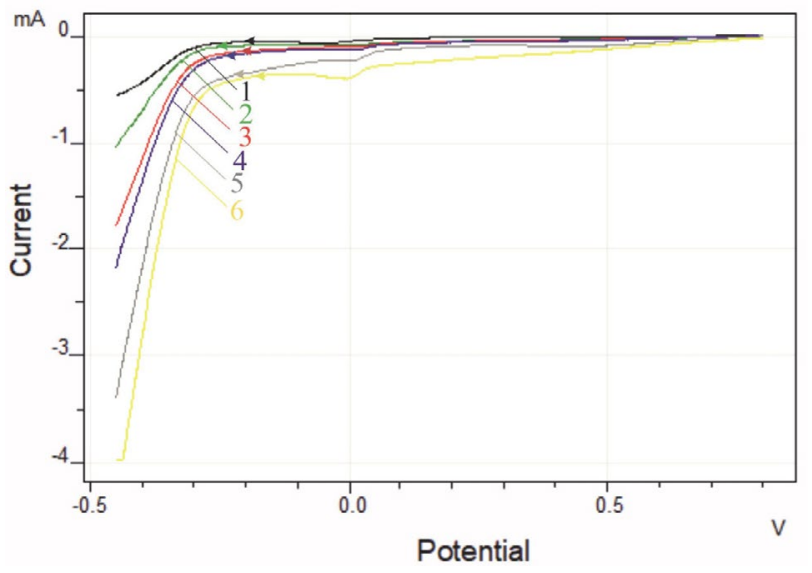

Fig. 5. The effect of potential-scanning to the electroreduction process of the molybdate ions on the Pt electrode. Electrolyte (M): 0,1 $\mathrm{Na}_{2} \mathrm{MoO}_{4} 2 \mathrm{H}_{2} \mathrm{O}+0,007 \mathrm{C}_{4} \mathrm{H}_{6} \mathrm{O}_{6}$. Potential-scanning (V/s): 10,$005 ; 2-0,01 ; 3-0,03 ; 4-0,06 ; 5-0,09 ; 6-0,12$. T = $293 \mathrm{~K}$.
0.1-0.3 M, the effect is regular. In more precisely, with increasing of the concentration of the ions the electrochemical reduction takes place at more positive potentials. Within these intervals $(0.3-0.5 \mathrm{M})$ the displacement of reduction potential to the negative side is observed. It can be interpreted as, with increasing of the concentration of the molybdate ions their mobilities in the electrolyte decrease, and then the electroreduction process becomes hard. Furthermore, at the high concentration, the molybdate ions form a stable complex with tartaric acid.

Therefore, their subsequent dissociation becomes difficult. As a result of the investigation, the optimal conditions have been detected, then we selected the optimal concentration of the molybdate ions up to $0.2 \mathrm{~mol} / \mathrm{L}$.

The effect of potential scanning onto the electroreduction process of the molybdate ions has been studied in the potential range of $-0,27-(-0,32) \mathrm{V}$ as shown in Fig. 5 . As seen from Fig. 5, with increasing of potential scanning, the consumed current for the electroreduction process of the moybdate ions is increased. Where, current at $0.005 \mathrm{~V} /$ sec is $5.53 \times 10^{-4} \mathrm{~A}$, whereas at $0.12 \mathrm{~V} / \mathrm{sec}$ is $3.97 \times 10^{-3} \mathrm{~A}$.

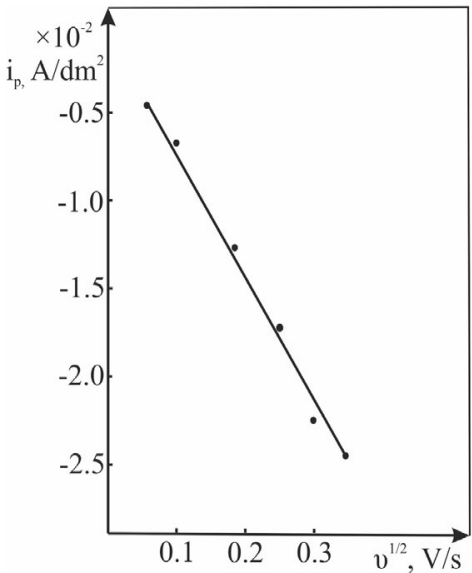

Fig. 6. $i_{p}$ as a function of $v^{1 / 2}$ for electroreduction of the molybdate ions. Electrolyte (M): 0,1 Na $\mathrm{NoO}_{4} 2 \mathrm{H}_{2} \mathrm{O}+0,007 \mathrm{C}_{4} \mathrm{H}_{6} \mathrm{O}_{6}, \mathrm{~T}=293$ K.

Fig. 6 indicates that the relationship between $i_{p}$ and $v^{1 / 2}$ is linear. It also demonstrates that the electroreduction process of the molybdate ions occurs under the control of concentration polarization overpotential.

The chronoamperometric (CA) method can be easily used for giving more precise information about the electrochemical deposition process, at which the potential can be stopped at the deposition potential (from CV). Via CA method, the mechanisms of the nucleation and growth of the electrodeposited particles can be studied. Current-time curves were carried out at different applied potentials of $0.047 ; 0.03 ;-0.06 ;-0.09$; and $-0.1 \mathrm{~V}$ at room temperature as shown in Fig. 7. It seems from the shown figure that the initial regime of the current-time curve is characterized by a sudden decrease in the current under application of the 
deposition potential. This can be attributed to the presence of the double-layer between the surface of the substrate and the ions of the solution, which lead to the formation of an immediate nucleation of molybdenum in all cases as shown in Fig. 7.

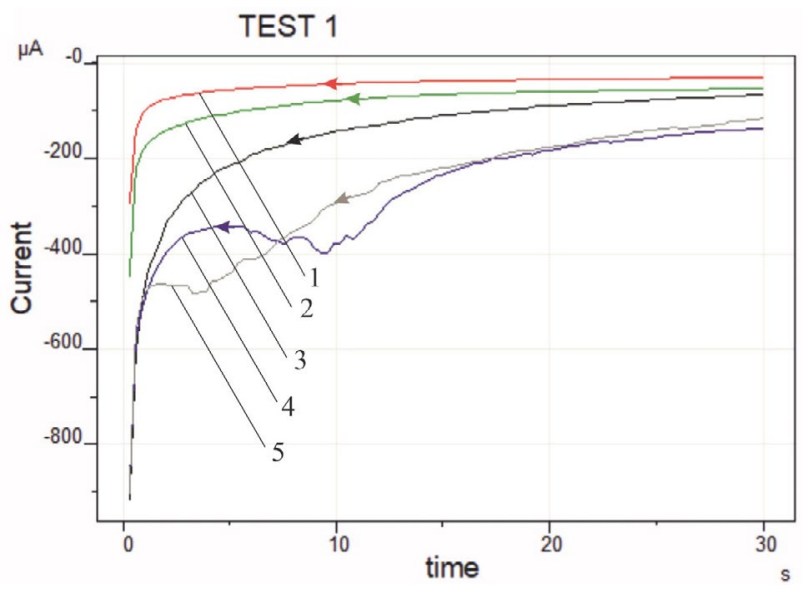

Fig. 7. Current-time curves of the electrodeposition of molybdenum on Pt in electrolyte consists of $0.1 \mathrm{M} \mathrm{Na}_{2} \mathrm{MoO}_{4} 2 \mathrm{H}_{2} \mathrm{O}+0.007 \mathrm{M}$ $\mathrm{C}_{4} \mathrm{H}_{6} \mathrm{O}_{6}$ at $\mathrm{T}=295 \mathrm{~K}$ at room temperature and at different deposition potentials; 0,$047 ; 0.03 ;-0.06 ;-0.09$; and $-0.1 \mathrm{~V}$ vs. Ag/AgCl.

This sudden decrease is followed by a little increase in the resultant current. This due to an increase in the electroactive surface area associated with the crystal growth. Moreover, it can be noted that the current density during the electrodeposition increases in all cases by increasing the deposition potential. The mechanism of crystal nucleation and growth can be determined by the analysis of the resulted current-time curves. The analysis of these curves can be achieved by applying the two equations of Scharifker-Hills, ${ }^{21}$ comparing with the experimental calculated data as shown in Fig. 8 (a-e). The models of the theoretical transients for the instantaneous and the progressive 3D nucleation are given by equations (4) and (5), respectively as follows:

$$
\begin{aligned}
& \frac{I(t)^{2}}{I_{\max }}=\frac{1.9542}{t / t_{\max }}\left\{1-\exp \left[-1.2564\left[\frac{t}{t_{\max }}\right]\right]\right\}^{2} \\
& \frac{I(t)^{2}}{I_{\max }}=\frac{1.2254}{t / t_{\max }}\left\{1-\exp \left[-2.3367\left[\frac{t}{t_{\max }}\right]^{2}\right]\right\}^{2}
\end{aligned}
$$

Fig. 8 (a-e) shows the nondimensional $\mathrm{I}^{2} \cdot \mathrm{I}^{2}{ }_{\max }$ vs. $\mathrm{t}$. $t_{\max }$ plots of the CA data at the different condition as in Fig. 7. The solid lines of black and red color are the theoretical transients of the instantaneous and the progressive nucleation, respectively as shown in the figure, and dotted lines for the experimental data. The nucleation and growth processes of molybdenum at these conditions can be predicted from Fig. 8 (a-e). At the early stage, the experimental curve well fits the curve of the progressive nucleation model by which the molybdenum nucleation occurred on many active sites of $\mathrm{Pt}$ surface substrates. Subsequently, the deposition deviates from the instantaneous nucleation as shown in Fig. 8 (a, b, c, and d). The deviation from the ideal assumption of the Scharifker model may be attributed to that the nuclei grow under diffusion control at these conditions.

In fact, through time the nuclei growth and the electrodeposition of molybdenum will be under mixed control (diffusion and charge transfer). The deviation can be also interpreted as due to the hydrogen reduction during the formation of nuclei which cause morphology change of the nucleus. But, the experimental data for Fig. 8 e are in a good agreement with the theoretical model of the progressive nucleation and growth where the deposition potential of $0.1 \mathrm{~V}$. Further information for the growth mechanism can be obtained by calculating the density number of actives sites for nucleation $\left(\mathrm{N}_{0}\right)$;

$$
N_{0}=0.065\left(\frac{8 \pi C M}{\rho}\right)^{-1 / 2}\left(\frac{z f C}{t_{\max } i_{\max }}\right)^{2}
$$

where, $\mathrm{C}$ the bulk concentration in $\mathrm{mol} \mathrm{cm}{ }^{-3}$, $\mathrm{zf}$ the molar charge of electrodepositing species, $\mathrm{M}$ and $\rho$ in $\mathrm{g} \mathrm{cm}^{-3}$ are the molecular weight and the density of the deposited material, respectively. The diffusion coefficient $\mathrm{D}$ of the active species in the electrolyte can be calculated via the chronoamperometric method. According to the theoretical nucleation model, the $D$ is related to the $i_{\max }$ and the $t_{\max }^{21,22}$ by the following equation;

$$
\mathrm{D}=\frac{i_{\max }{ }^{2} t_{\max }}{0.1629(z f C)}
$$

The values of $\mathrm{i}_{\max }, \mathrm{t}_{\max }, \mathrm{D}$, and $\mathrm{N}_{0}$ at different deposition potentials and temperatures are shown in Table 1. From these values, it is clear that by increasing the deposition potential, the $i_{\max } t_{\max }$ value slightly increases. This character is typical for $3 \mathrm{D}$ electrochemical nucleation and growth of a new phase under the mixed diffusion and adsorption control.

Moreover, the $\mathrm{D}$ values at these conditions of the electroactive species are very small due to the high relative density of the electrolyte and the high relative diameter of molybdate ions. It is also observed that the $\mathrm{D}$ value is affected by the polarization potential as seen in Table 1 .

Table 1. The experimental data of the CA electrodeposition of Mo onto Pt substrate

\begin{tabular}{ccc}
\hline $\boldsymbol{E}_{\mathbf{d}}, \mathbf{V}$ vs. Ag/AgCl & $\boldsymbol{D}, \mathbf{c m}^{\mathbf{2}} \mathbf{s}^{\mathbf{- 1}}$ & $\boldsymbol{N}_{\mathbf{0}}, \mathbf{c m}^{-\mathbf{2}}$ \\
\hline 0.047 & $1.89 \times 10^{-9}$ & $25.10 \times 10^{6}$ \\
0.030 & $3.54 \times 10^{-9}$ & $8.51 \times 10^{6}$ \\
-0.06 & $5.61 \times 10^{-9}$ & $5.38 \times 10^{6}$ \\
-0.09 & $8.24 \times 10^{-9}$ & $1.26 \times 10^{6}$ \\
-0.10 & $10.17 \times 10^{-9}$ & $1.07 \times 10^{6}$ \\
\hline
\end{tabular}



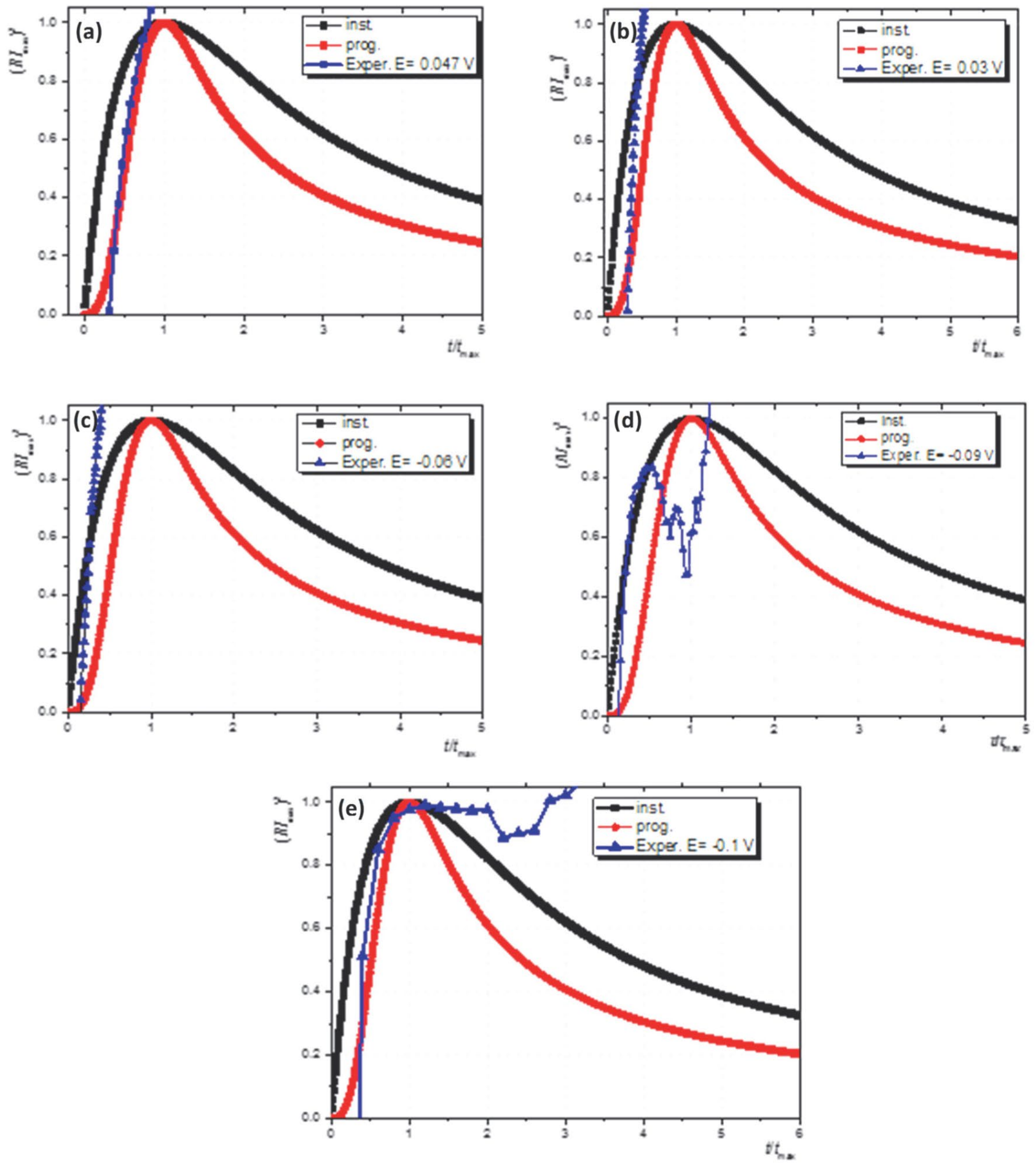

Fig. 8. Comparison of theoretical non-dimensional plots of $\left(\mathrm{I} / \mathrm{I}_{\max }\right)^{2} \mathrm{vs}\left(\mathrm{t} / \mathrm{t}_{\max }\right)$, for instantaneous and progressive nucleation with the experimental data derived from Fig. 7.

It is noted from the table that nuclei densities $\mathrm{N}_{0}$ decrease significantly with the increase of the deposition potential. This decrease with the applied deposition potential is generally understood as the decreased of the activation of the nucleation sites at higher potentials, which deviates from the classical nucleation models as confirmed by Fig. 7. This deviation may be also explained as, by increasing the deposition potential the polarization of the working electrodes increases but the diffusion of the active species is still slow because of the high density of surrounding media which hinder the diffusion of the active species.

Fig. 9. shows the morphology and chemical composition of electrodeposits of the metallic Mo films investigated by SEM and EDX. Mapping SEM images and EDX 

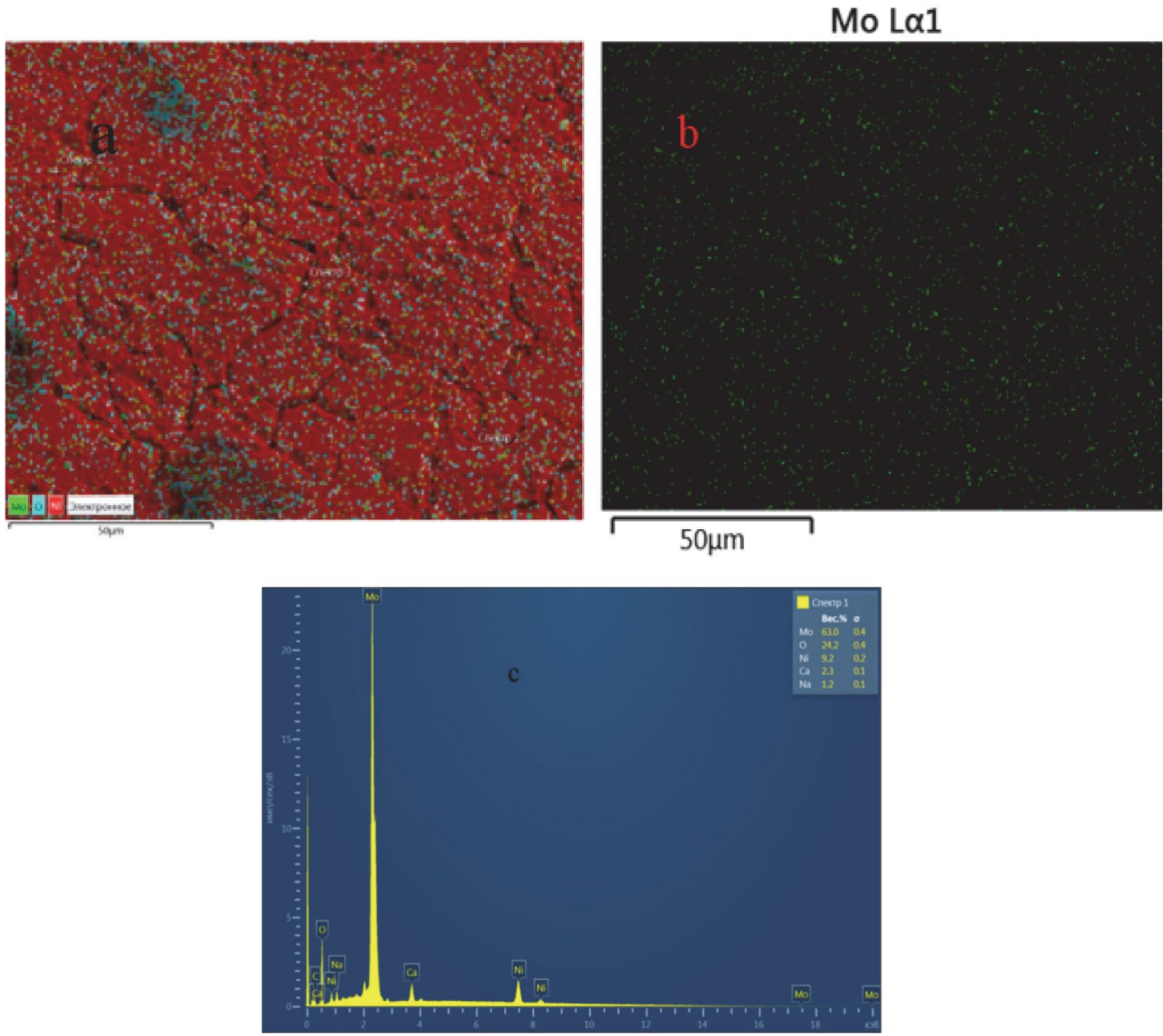

Fig. 9. $\operatorname{SEM}(\mathrm{a}, \mathrm{b})$ and $\operatorname{EDAX}(\mathrm{c})$ of the electrodeposited Mo from a solution consists of $0,1 \mathrm{M} \mathrm{Na}_{2} \mathrm{MoO}_{4} 2 \mathrm{H}_{2} \mathrm{O}+0.007 \mathrm{M} \mathrm{C} \mathrm{H}_{6} \mathrm{O}_{6}$ at the potential of $\mathrm{E}=-0.4 \mathrm{~V}$, at scan rate $=0.02 \mathrm{Vs}^{-1}$ on Ni electrode at $\mathrm{T}=295 \mathrm{~K}$

analysis show that the quantity of metallic molybdenum is more than that of oxygen. The presence of oxygen may be returned to that there are some adsorbed molybdate ions on the electrode surface come from the electrolyte.

Both Fig. 9a and $9 \mathrm{~b}$ refer to the molybdenum sample deposited at $\mathrm{E}=-0.4 \mathrm{~V}$ potential. Figure 9a presents the general SEM description including nickel electrode, molybdenum and oxygen components. That is, the area marked with red indicates the $\mathrm{Ni}$ electrode, blue colored dots show the oxygen in the sample, and the green dots are molybdenum. Fig. $9 \mathrm{~b}$ represents only the molybdenum film, in order to demonstrate its deposition more noticeably.

As a result of the conducted experiments, the electroreduction of the molybdate ions has been implemented from an electrolyte consists of $0.1 \mathrm{M} \mathrm{Na}_{2} \mathrm{MoO}_{4} 2 \mathrm{H}_{2} \mathrm{O}$ and
$0.007 \mathrm{M} \mathrm{C}_{4} \mathrm{H}_{6} \mathrm{O}_{6}$, at a potential scan rate of $0.02 \mathrm{Vs}^{-1}$ and temperature of $295 \mathrm{~K}$. EDX analysis shows a good quality of the electrodeposited film from the chemical composition Mo and other elements.

\section{Conclusions}

The electroreduction process of the molybdate ions from tartaric acid solutions has been investigated on the $\mathrm{Pt}$ electrode. Kinetics and mechanism of the process have been studied, using the data of cyclic and linear polarization curves. The nature of polarization process in this case is accompanied by mixing kinetics. The results of all performed experiments indicate that the concentration of the molybdate ions, temperature and potential scanning have 
a great effect on the electroreduction process of the molybdate ions in the tartaric acid electrolytes. The optimal conditions and the composition of electrodeposition bath for electroreduction process of the molybdate ions was preciously detected. The electrolyte composition consists of $0.1 \mathrm{M} \mathrm{Na}_{2} \mathrm{MoO}_{4} 2 \mathrm{H}_{2} \mathrm{O}+0.007 \mathrm{M} \mathrm{C}_{4} \mathrm{H}_{6} \mathrm{O}_{6}$. The electrolysis conditions are detected to be as follow: temperature $295 \mathrm{~K}$, scan-rate $0.02 \mathrm{Vs}^{-1}$, electrode $\mathrm{Pt}$ and $\mathrm{Ni}, \mathrm{pH}=2.1$. In addition, using galvanostatic deposition technique, where thin films of molybdenum were obtained at a current density of $2-4 \mathrm{~mA} / \mathrm{cm}^{2}$, at electrolysis time of $360-470$ minutes. The results of the EDX analysis show that $63 \%$ of metallic molybdenum in the deposited thin films.

\section{Reference}

1. A. Sh. Aliyev, Sh. O. Eminov, B. Sh. Sultanova, V. A. Mejidzadeh, D. A. Kuliyev, D. Jalilova, D. B. Tagiyev, Chemical Problems. 2016, 2, 139-145.

2. M. Duda, R. Kowalik, K. Mech, P. R. Zabinski, Rudy Met. Niezel. 2012, 9, 586-591. DOI:10.1016/j.mssp.2015.01.006

3. A. Sh. Aliyev, M. Elrouby, S. F. Cafarova, Mat. Sci. Semicon. Proc. 2015, 32, 31-39.

4. F. Golgovici, T. Visan, M. Buda, Chalcogenide Lett. 2013, 6, 197-207.

5. M. R. Palacín, P. Simon, J. M. Tarascon, Acta Chim. Slov. 2016, 63, 417-423. DOI:10.17344/acsi.2016.2314

6. G. M. Huseynov, N. A. Mammadova, H. A. Imanov, Chemical Problems. 2017, 3, 329-334.

DOI:10.32737/2221-8688-2017-3-329-334

7. V. A. Majidzade, P. H. Guliyev, A. Sh. Aliyev, M. Elrouby, D. B. Tagiyev, J. Mol. Struct. 2017, 1136, 7-13.

DOI:10.1016/j.molstruc.2017.01.082
8. V. A. Majidzade, Sh. E. Alizade, A. Sh. Aliyev, Nakhchivan State University Scientific works. 2018, 92, 3, 176-179.

9. A. Sh. Aliyev, V. A. Majidzade, N. Sh. Soltanova, D. B. Tagiyev, V. N. Fateev, Chemical Problems. 2018, 2, 178-185.

DOI:10.32737/2221-8688-2018-2-178-185

10. V. A. Majidzade, Chemical Problems. 2018, 3, 331-336. DOI:10.32737/2221-8688-2018-3-331-336

11. V. A. Majidzade, S. F. Cafarova, A. Sh. Aliyev, D. B. Tagiyev, Azerbaijan Chemical Journal. 2018, 3, 6-10.

DOI:10.32737/0005-2531-2018-3-6-10

12. K. Ogura, Y. Enaka, T. Yosino, Electrochim. Acta. 1977, 5, 509-512. DOI:10.1016/0013-4686(77)85113-X

13. P. Zanello, G. Raspi, A. Cinquantini, Talanta. 1977, 1, 25-30.

14. V. V. Kuznetsov, D. I. Zimakov, S. A. Chepeleva, V. N. Kudryavtsev, Russ. J. Electrochem. 2004, 40, 7, 711-715. DOI:10.1023/B:RUEL.0000035253.18329.98

15. S. F. Cafarova, A. Sh. Aliyev, M. Elrouby, N. Sh. Soltanova, D. B. Tagiyev, J. Electrochem. Sci. Eng. 2015, 4, 231-235.

16. N. D. Ivanova, S. V. Ivanov, E. I. Boldyrev, O. A. Stadnik, Prot. Met. Phys. Chem. 2006, 4, 388-392.

17. S. Rajak, S. K. Ghosh, P. U. Sastry, G. Sharma, R. C. Hubli, J. K. Chakravartty, Surf. Coat. Tech. 2015, 261, 15-20. DOI:10.1016/j.surfcoat.2014.11.073

18. S. M. Deambrosis, E. Miorin, F Montagner, V. Zin, M. Fabrizio, M. Sebastiani, F. Massimi, E. Bemporad, Surf. Coat. Tech. 2015, 266, 14-21. DOI:10.1016/j.surfcoat.2015.02.006

19. T. J. Morley, L. Penner, P. Schaffer, T. J. Ruth, F. Bénard, E Asselin, Electrochem. Commun. 2012, 1, 78-80.

DOI:10.1016/j.elecom.2011.11.026

20. A. A. Sukhotin (Ed): Handbook of Electrochemistry, Chemistry, Leningrad, Russian, 1981, p. 488.

21. B. Scharifker, G. Hills, Electrochim. Acta. 1983, 28, 7, 879889. DOI:10.1016/0013-4686(83)85163-9

22. M. R. Khelladi, L. Mentar, A. Azizi, A. Sahari, A. Kahoul, Mater. Chem. Phys. 2009, 115, 385-390.

DOI:10.1016/j.matchemphys.2008.12.017

\section{Povzetek}

V tem delu smo raziskovali redukcijski potencial molibdatnih ionov v tartarski kislini kot elektrolitu. Študirali smo kinetiko in mehanizem elektrokemijskega procesa s ciklično in linearno voltametrično polarizacijsko metodo. Študirali smo vpliv temperature, hitrosti spreminjanja potenciala in koncentracije molibdatnih ionov na elektrokemijski proces. Ocena efektivne aktivacijske energije je pokazala, da je elektrokemijski proces kontroliran s kinetiko mešanja. 